\title{
Isolation and Screening of Potential Cellulolytic and Xylanolytic Bacteria from Soil Sample for Degradation of Lignocellulosic Biomass
}

Sanjaya Ghimire, Shakep Bhattarai, Sailesh Phuyal, Bimal Thapa, Bhupal Govinda Shrestha*

Department of Biotechnology, School of Science, Kathmandu University, Dhulikhel, Nepal

\section{ABSTRACT}

Cellulolytic/Xylanolytic microorganisms such as bacteria and fungi are accountable for conversion of lignocellulosic biomass in soil. Despite this vast number of cellulose/xylanase producers, there is a deficiency of microorganisms that can produce a significant amount of cellulase/xylanase enzyme to proficiently degrade cellulose/xylan to fermentable sugars. Although bacteria have extremely high natural diversity, which bestows them with the aptitude to produce stable enzymes, little emphasis has been given to cellulose/xylanase production from bacteria. Seven soil samples were collected from eastern hilly districts of Nepal viz. Taplejung, Panchthar and Sankhuwasabha districts, from soil surface and at depth of $10 \mathrm{~cm}$ to $20 \mathrm{~cm}$, and were isolated separately. From the seven soil samples, four bacterial isolates were obtained. Isolates (PSS, P1D, TLC, SNK) were then screened for cellulolytic/xylanolytic activity using Congo red assay on Carboxymethylcellulose (CMC)/xylan agar plates. The enzyme activity obtained from isolates was dependent on substrate concentration. The activity of enzymes produced by isolates were also measured and compared on pretreated sugarcane bagasse. Among those samples, the greatest zone of inhibition in both CMC $(1.3 \mathrm{~cm})$ and xylan $(1.0 \mathrm{~cm})$ agar media was seen in isolate P1D. It also produced the highest activity of endoglucanase and xylanase i.e. activity $0.035 \mathrm{U} / \mathrm{mL}$ and $0.050 \mathrm{U} / \mathrm{mL}$ respectively at $0.010 \mathrm{mg} \mathrm{mL}-1$ standard substrate concentration of CMC and xylan.

Keywords: Lignocellulosic biomass, Cellulase, Xylanase, Enzyme activity, Pretreatment

\section{INTRODUCTION}

In nature polysaccharide degrading enzymes such as cellulase, xylanase and amylase are pervasively found in various types of organism, including mammals, plants, algae, molds, bacteria and phages [1]. Among them, microorganisms are generally the most opportune sources for the production of polysaccharides and are also can be found from various natural environments [2].

Lignocellulosic material consists of cellulose, hemicellulose, and lignin as their main constituents. Cellulose is a linear polymer of glucose linked through $\alpha-1$, 4-linkages and is usually arranged in microcrystalline structures, which makes it very arduous task to dissolve or hydrolyze under natural conditions [3]. Hemicellulose is a heteropolysaccharide composed of different hexoses, pentoses, and glucoronic acid. Xylan is the

\footnotetext{
${ }^{*}$ Corresponding author:

Bhupal Govinda Shrestha

Department of Biotechnology, School of Science, Kathmandu

University, PO Box 6250, Dhulikhel, Nepal

E-mail address: bgs@ku.edu.np
}

most common hemicellulose component of grasses and woods [4].

The increasing utility of lignocellulose wastes is known for decades. In addition to the growing demand for traditional applications like biomass fuels, paper manufacture, composting, animal feed, etc. novel markets for lignocellulose are identified in recent years [5].

As commercial viability seemed probable, through new applications, research and capital investment in this field has increased immensely. The most striving of these is the conversion of lignocellulose to alternative energy sources like ethanol, acetone, and butanol $[6,7]$.

Successful bioconversion of lignocellulosic materials mainly depends on the nature of lignocellulosic biomass, sources of cellulolytic/xylanolytic enzyme and optimal conditions for enzymatic activity and produc-

\footnotetext{
How to cite:

Sanjaya G, Shakep B, Sailesh P et al. (2016) Isolation and Screening of Potential Cellulolytic and Xylanolytic Bacteria from Soil Sample for Degradation of Lignocellulosic Biomass. J. Trop. Life. Science 6 (3): $165-169$.
} 
tion of enzymes $[8,9]$.

Enzymes such as cellulase and xylanase have massive applicability. Thus, they have been used in imperative industrial processes such as biofuels like bioethanol production $[10,11,12]$, agricultural and plant waste management $[13,14]$.

Therefore, the motive of this study was to investigate novel bacteria that can produce cellulase and $\mathrm{xy}-$ lanase enzyme. It is an answer to industrial requirements such as high enzyme activity, broader substrate utilization, and work in wide range of temperature and $\mathrm{pH}$. Our study also focuses on providing useful information for assessing the feasibility of simultaneous saccharification and fermentation (SSF) process involving bacterial hydrolysis and ethanol fermentation from lignocellulosic biomass. It is all vital to reduce the processing cost of bioethanol.

\section{MATERIALS AND METHODS}

\section{Sample collection and preparation}

Soil samples from Eastern hilly districts of Nepal like Sankhuwasabha, Panchthar, and Taplejung were collected for the isolation of lignocellulose-degrading bacteria. These samples were brought to Kathmandu University laboratory maintaining cold chain and stored at $4^{\circ} \mathrm{C}$.

Cellulolytic/Xylanolytic bacterial strains were isolated from soil by using serial dilution and pour plate technique. The media used for isolation of cellulolytic bacteria contained $1.7 \%$ tryptone, $0.3 \%$ peptone, $0.5 \%$ CMC, $0.25 \%$ dipotassium phosphate (K2HPO4), 1.8\% agar, and $0.5 \%$ sodium chloride $(\mathrm{NaCl})(\mathrm{CMC}$ agar plate). For isolation of xylanolytic bacteria, all constituents were kept the same except that 0.5\% CMC was replaced by $0.5 \%$ Birchwood xylan in an agar plate. They were incubated at $37^{\circ} \mathrm{C}$ for 48 hours. Bacterial colonies were purified by repeated subculture. The purified colonies were preserved at $4^{\circ} \mathrm{C}$ for further identification and screening for cellulose/xylanase production.

\section{Screening of Cellulolytic/Xylanolytic bacteria}

Pure cultures of bacterial isolates were individually transferred to CMC/Xylan agar plates. After incubation for 48 hours, agar plates were flooded with $1 \%$ Congo red and allowed to stand for 15 minutes at room temperature. $1 \mathrm{M} \mathrm{NaCl}$ was used for counterstaining the plates. Clear zones appeared around growing bacterial colonies indicating cellulose/Xylan hydrolysis. The bacteria having the distinct and measurable zones were selected for identification and enzyme assay
Table 1. Diameter of zone of inhibition of PSS, TLC, P1D and SNK on CMC/Xylan agar plates using Congo red test $\left({ }^{*}\right.$ no significant growth seen $)$

\begin{tabular}{cccc}
\hline \multirow{2}{*}{ No. } & Sample name & \multicolumn{2}{c}{ Diameter (zone of inhibition) $(\mathrm{cm})$} \\
\cline { 3 - 4 } & & $C M C$ & Xylan \\
\hline 1. & P1D & 1.3 & 1.0 \\
2. & TLC & 1.2 & $*$ \\
3. & PSS & 1.0 & 0.8 \\
4. & SNK & 1.2 & $*$ \\
\hline
\end{tabular}

The isolates which showed significant zone of inhibition were named Pathivara soil sample (P1D), Panchthar soil sample (PSS), Taplejung Lichen soil sample (TLC) and Sankhuwasabha soil sample (SNK).

\section{Enzyme production}

The isolates were cultured at $37^{\circ} \mathrm{C}$ in $\mathrm{CMC}$ and Xylan broth for crude enzyme extraction. Broth culture after 48 hours of incubation period was subjected to centrifugation at $2000 \mathrm{rpm}$ for 20 minutes. The supernatant was collected and stored as crude enzyme preparation at $4^{\circ} \mathrm{C}$ for further enzyme assay.

\section{Enzyme Assay (determination of endoglucanase and xylanase activity)}

For determination of endoglucanase activity, $500 \mu \mathrm{L}$ of the crude enzyme from CMC broth of three different samples were taken separately. These samples were mixed with $500 \mu \mathrm{L}$ standard $\mathrm{CMC}$, with increasing concentration $(0.25 \%, 0.5 \%, 1.0 \%$ and $2.0 \%$ respectively), in $0.05 \mathrm{M}$ sodium citrate $\left(\mathrm{Na}_{3} \mathrm{C}_{6} \mathrm{H}_{5} \mathrm{O}_{7}\right)$ buffer $(\mathrm{pH} 4.8)$ and incubated at $50^{\circ} \mathrm{C}$ for 1 hour. The same procedure was repeated for xylanase activity except that the crude enzyme was taken from xylan broth of different samples and mixed with increasing concentration of xylan. Enzyme control was prepared by mixing 50 $\mathrm{mM}$ sodium acetate $\left(\mathrm{CH}_{3} \mathrm{COONa}\right)$ buffer $(\mathrm{pH} 4.8)$ with different enzymes respectively. Substrate control was prepared by mixing different concentration of substrates (CMC/Xylan) with $0.05 \mathrm{M} \mathrm{CH}_{3} \mathrm{COONa}$ buffer ( $\mathrm{pH} 4.8$ ) respectively.

The optimized pretreatment strategy $(2 \% \mathrm{NaOH}$ with 1:50 substrate ratio for 30 minutes) was done with sugarcane bagasse to make Cellulose/Xylan accessible. Determining the enzymatic activity of different crude enzymes in sugarcane bagasse solution was done by adding $500 \mu \mathrm{L}$ of $0.1 \mathrm{mg} / \mathrm{mL}$ sugarcane bagasse solution with $0.05 \mathrm{M} \mathrm{CH}_{3} \mathrm{COONa}$ buffer $500 \mu \mathrm{L}$ crude enzymes. It was incubated at $50^{\circ} \mathrm{C}$ for 1 hour.

After incubation, the reaction was terminated by 
adding $3 \mathrm{~mL}$ of 3,5-dinitrosalicylic acid (DNS) reagent to the reaction mixture. Then the reducing sugars were estimated spectrophotometrically with DNS using standard glucose/xylose curve respectively. Endoglucanase and xylanase activity were defined in international units (IU).

\section{RESULTS AND DISCUSSION}

\section{Isolation and screening of Cellulose/Xylan degrading bacteria}

Out of the seven samples screened, four samples (PSS, TLC, P1D and SNK) showed halo region while performing Congo red test of CMC agar plates. Whereas, only two (PSS and P1D) showed distinct halo region in xylan agar plates during the test (Table 1 and Figure 1).

\section{Calculation of enzyme activity}

Cellulolytic/Xylanolytic microorganisms such as fungi and bacteria are responsible for much of the cellulose/xylan degradation in soils [15]. Despite this vast number of cellulase/xylanase producers, there is a deficiency of microorganisms that can produce a significant amount of endoglucanases which is one of the major part of cellulase enzyme [16]. In addition to this, the majority of the studies have been focused on fungi with less emphasis on bacterial sources for cellulase/xy- lanase production. Due to their extremely high natural diversity, bacteria have the capability to produce stable enzymes that can be applied in industries such as biorefinery [17] and due to their high growth rate as compared to fungi they have good potential to be used in cellulase/xylanase production [18]. These two factors were the prime motivation for this study; to isolate and screen the potential of bacteria to degrade lignocellulose from extreme environments such as hilly region.

The formation of clearing zone around the colonies pointed by arrow on samples as seen in Figure 1 confirms the secretion of extracellular cellulase and $x y-$ lanase enzyme [19, 20].

Extraction of enzymes was confirmed by series of enzyme assays for the determination of enzyme activity. The CMCase and xylanase assays performed so forth to check the enzyme activity. Among the samples collected, the enzymes extracted from sample P1D showed higher cellulase activity compared to the enzyme from other samples SNK and PSS as shown in Figure 2a. The xylanase activity was also found higher in P1D sample compared to other two samples as seen in Figure 2b.

Enzyme activities of these samples were also determined on sugarcane bagasse as substrate and compared with each other. The activity value obtained from samples grown in CMC media showed that sample SNK
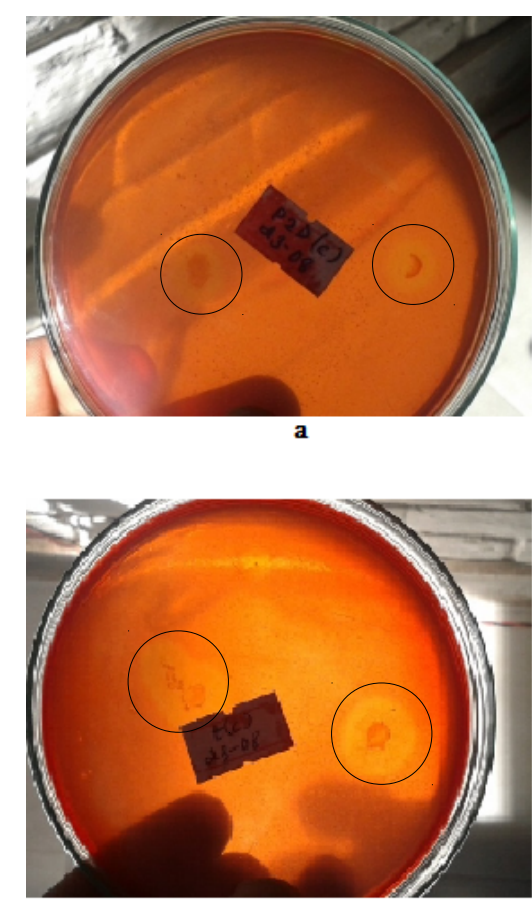

d
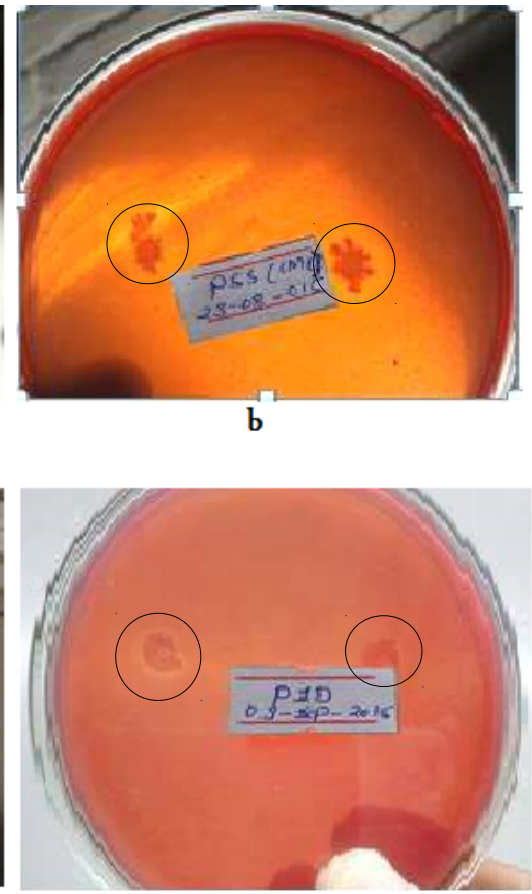

e

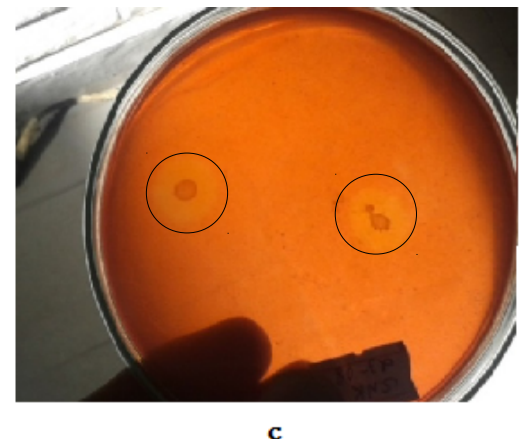

c

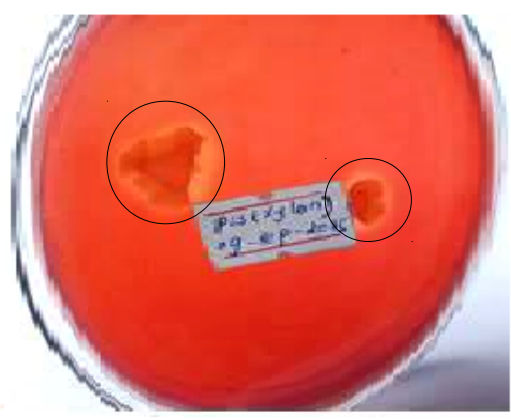

f

Figure 1. Clearance zone of soil samples on different agar plates was created after 48 hours of incubation. P1D, PSS, SNK, and TLC were on CMC Congo Red agar (a, b, c, and d). P1D and PSS were on Xylan Congo Red agar (e and f). 


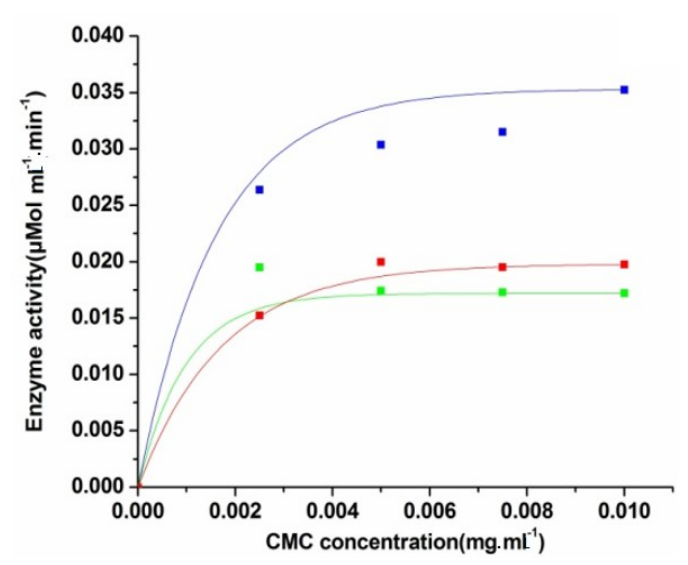

(a)

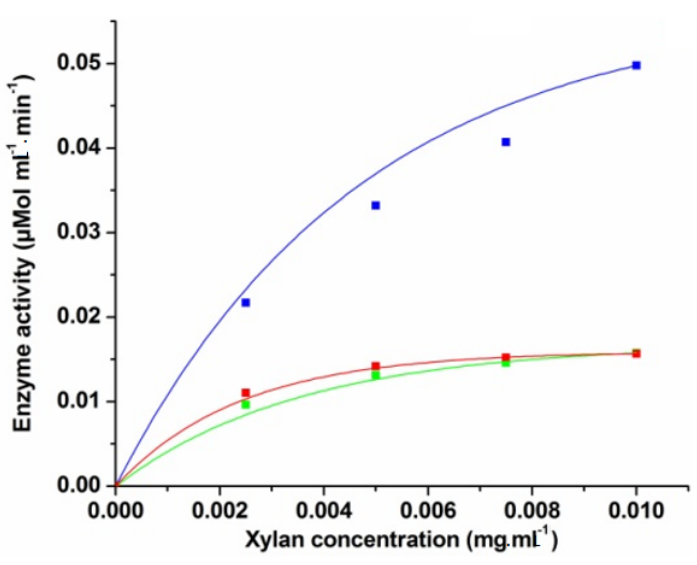

(b)

Figure 2. Enzyme activity of P1D, PSS and SNK sample grown in CMC (a) and Xylan media (b) ( — : P1D, — : PSS, and — : SNK)

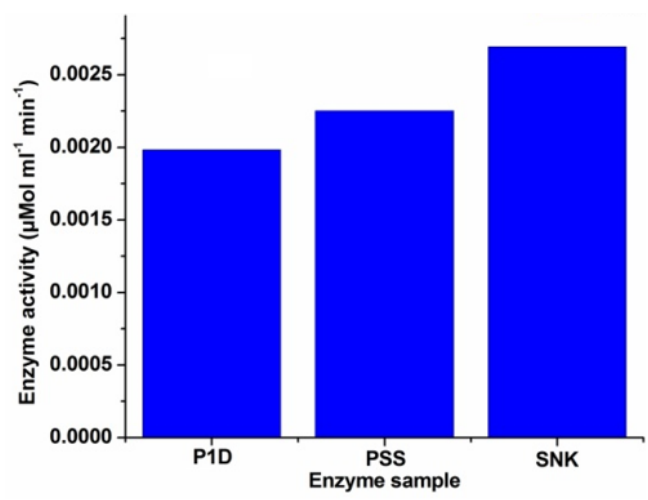

(a)

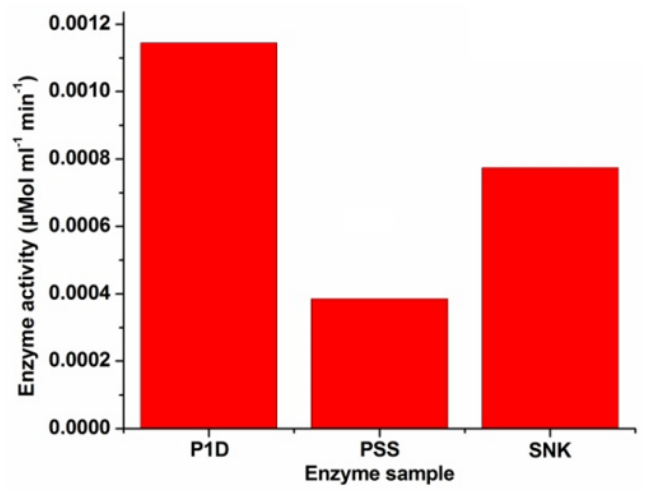

(b)

Figure 3. Comparative enzyme activity of sample in different sugarcane bagasse as substrates: CMC broth (a) and Xylan broth (b)

has the highest value (Figure 3a) whereas activity value obtained from the sample grown in xylan media showed the highest value for sample P1D (Figure 3b). This suggests that SNK grown in CMC media and P1D grown in xylan media, has the best enzyme activity in the substrate bagasse.

The activities of enzymes produced by soil sample bacteria are found to be higher than those produced by ruminant gut bacteria under same experimental design. This higher value of enzyme activity $(0.050 \mathrm{U} / \mathrm{mL})$ compared to $0.022 \mathrm{U} / \mathrm{mL}$ produced from ruminant gut bacteria [21], suggests that the enzymes produced from soil bacteria at extreme conditions are better source of enzymes for lignocellulose conversion to fermentablee product. 1 unit enzyme activity is expressed as the quantity of enzyme which is required to release $1 \mu \mathrm{mol}$ of glucose per minute under standard assay condition.

\section{CONCLUSION}

This research found different soil microorganisms that have shown cellulolytic and xylanolytic activity. The zone of inhibition on plates suggested the microorganisms present in culture are capable of producing enzymes that can utilize cellulosic and hemicellulosic substrate when available. Among the samples tested P1D exhibited the greatest cellulolytic and xylanolytic activity. Enzyme activity measurement showed higher activity value for sample P1D on standard CMC/xylan substrate. Higher enzyme activity value produced from soil samples compared to ruminants gut also put those microbes a potential source for lignocellulose conversion.

\section{ACKNOWLEDGMENT}

This paper is based on research financed under the Climate Change Research Grants Program implemented by the Nepal Academy of Science and Technology. The Program is part of the Mainstreaming Climate Change Risk Management in Development project. This project is a component of Nepal's Pilot 
Program for Climate Resilience and is executed by the Ministry of Population and Environment (Nepal), financed by the Climate Investment Funds, administered by the Asian Development Bank with technical assistance from ICEM, METCON and APTEC. The authors are also thankful to Department of Biotechnology, Kathmandu University, Nepal for providing research laboratory.

\section{REFERENCES}

1. Sutherland IW (1999) Polysaccharases for microbial exopolysaccharides. Carbohydrate Polymers 38 (4): 319328. doi: 10.1016/S0144-8617(98)00114-3.

2. Terra WR, Ferreira C (1994) Insect digestive enzymes: properties, compartmentalization and function. Comparative Biochemistry and Physiology -- Part B: Biochemistry and 109 (1): 1-62. doi: 10.1016/03050491(94)90141-4..

3. Chen H (2014) Chemical Composition and Structure of Natural Lignocellulose. In: Biotechnol. Lignocellulose. Theory Pract. 25-71.

4. Lee D, Owens VN, Boe A, Jeranyama P (2007) Composition of herbaceous biomass feedstocks. South Dakota, Brookings, SD: North Central Sun Grant Center.

5. Malherbe S, Cloete TE (2002) Lignocellulose biodegradation: Fundamentals and applications. Reviews in Environmental Science and Biotechnology 1 (2): 105114. doi: 10.1023/A:1020858910646.

6. Kaylen M, Van Dyne DL, Choi YS, Blase M (2000) Economic feasibility of producing ethanol from lignocellulosic feedstocks. Bioresource Technology 72 (1): 19-32. doi: 10.1016/S0960-8524(99)00091-7.

7. Lee J (1997) Biological conversion of lignocellulosic biomass to ethanol. Journal of Biotechnology 56 (1): 124. doi: 10.1016/S0168-1656(97)00073-4.

8. Irfan M, Safdar A, Syed Q, Nadeem M (2012) Isolation and screening of cellulolytic bacteria from soil and optimization of cellulase production and activity. Turkish Journal of Biochemistry 37 (July): 287-293. doi: 10.5505/tjb.2012.09709.

9. Saratale GD, Saratale RG, Oh SE (2014) Production and characterization of multiple cellulolytic enzymes by isolated Streptomyces sp. MDS. Biomass and Bioenergy 47 302-315. doi: 10.1016/j.biombioe.2012.09.030.

10. Gupta P, Samant K, Sahu A (2012) Isolation of cellulosedegrading bacteria and determination of their cellulolytic potential. Int J Microbiol. doi: 10.1155/2012/578925
11. Ekperigin MM (2007) Preliminary studies of cellulase production by A. cinetobacter anitratus and Branhamella sp. African J Biotechnol 6 (1): 28-33.

12. Uma Maheswari M, Chandra TS (2000) Production and potential applications of a xylanase from a new strain of Streptomyces cuspidosporus. World Journal of Microbiology and Biotechnology 16 (3): 257-263. doi: 10.1023/A:1008945931108.

13. Mosier N, Wyman C, Dale B et al. (2005) Features of promising technologies for pretreatment of lignocellulosic biomass. Bioresource Technology 96 (6): 673-686. doi: 10.1016/j.biortech.2004.06.025.

14. Kuhad RC, Gupta R, Singh A (2011) Microbial cellulases and their industrial applications. Enzyme Research 2011 280696. doi: 10.4061/2011/280696..

15. Trujillo-Cabrera Y, Ponce-Mendoza A, Vásquez-Murrieta MS et al. (2013) Diverse cellulolytic bacteria isolated from the high humus, alkaline-saline chinampa soils. Annals of Microbiology 63 (2): 779-792. doi: 10.1007/s13213-0120533-5.

16. Yennamalli RM, Rader AJ, Kenny AJ et al. (2013) Endoglucanases: insights into thermostability for biofuel applications. Biotechnology for biofuels 6 (1): 136. doi: 10.1186/1754-6834-6-136.

17. Almeida JRM, Fávaro LCL, Quirino BF (2012) Biodiesel biorefinery: opportunities and challenges for microbial production of fuels and chemicals from glycerol waste. Biotechnology for biofuels 5 (1): 48. doi: 10.1186/17546834-5-48.

18. Maki ML, Broere M, Leung KT, Qin W (2011) Characterization of some efficient cellulase producing bacteria isolated from paper mill sludges and organic fertilizers. International Journal of Biochemistry and Molecular Biology 2 (2): 146-154.

19. Bhat MK (2000) Cellulases and related enzymes in biotechnology. Biotechnology Advances 18 (5): 355-383. doi: 10.1016/S0734-9750(00)00041-0.

20. Okeke BC, Lu J (2011) Characterization of a defined cellulolytic and xylanolytic bacterial consortium for bioprocessing of cellulose and hemicelluloses. Applied Biochemistry and Biotechnology 163 (7): 869-881. doi: 10.1007/s12010-010-9091-0.

21. Kaphle P, Rana S, Bhandari J et al. (2014) Isolation and Optimization of Cellulolytic and Xylanolytic Microbes from Nepal and their Utilization for Lignocellulosic Biomass Degradation. International Journal of Interdisciplinary and Multidisciplinary Studies 1 (4): 1-10. 